\title{
CARBON DIOXIDE IN THE SOILS AND ADJACENT CAVES OF THE MORAVIAN KARST
}

\section{OGLJIKOVI DIOKSID V PRSTI IN JAMAH NA MORAVSKEM KRASU}

\author{
Jiří FAIMON ${ }^{1} \&$ Monika LIČBINSKÁ $^{1,2}$
}

\begin{abstract}
UDC 546.26:551.44(437.2)

Jiří Faimon \& Monika Ličbinská: Carbon dioxide in the soils and adjacent caves of the Moravian Karst

Variations of soil/cave $\mathrm{CO}_{2}$ concentrations and further variables such as temperature, humidity, and cave visitor attendance were studied in two sites of the Moravian Karst (Czech Republic). All the variables showed the same seasonality; they were strongly correlated with each other. The dependence of soil $\mathrm{CO}_{2}$ levels on soil air temperature and absolute humidity was confirmed. Individual effects could not be distinguished because of multicollinearity. The effect of vegetation on soil $\mathrm{CO}_{2}$ production was not recognized. Cave attendance was identified as the most significant predictor of cave $\mathrm{CO}_{2}$ levels. Other variables, soil $\mathrm{CO}_{2}$ and temperature gradients, were less significant. A spurious relationship was alternatively considered, in which external temperature was the universal predictor of cave $\mathrm{CO}_{2}$ levels.
\end{abstract}

Keywords: carbon dioxide, cave, correlation, multiple regression analysis, soil, spurious relationship, Chech Republic.
Izvleček UDK 546.26:551.44(437.2)

Jiří Faimon \& Monika Ličbinská: Ogljikovi dioksid v prsti in jamah na Moravskem krasu

Raziskovali smo spremembe koncentracije $\mathrm{CO}_{2}$ in drugih spremenljivk, kot so temperatura, vlaga in prisotnost turistov $\mathrm{v}$ jamah Moravskega krasa (Republika Češka). Vse spremenljivke kažejo podobne letne trende in so med seboj korelirane. Dokazali smo povezavo med koncentracijo $\mathrm{CO}_{2}$ ter temperaturo in vlago v prsti. Posamezne vplive zaradi multikolinearnosti nismo mogli izločiti. Vpliva vegetacije na produkcijo $\mathrm{CO}_{2} \mathrm{v}$ prsti nismo zaznali. Prisotnost ljudi v jami se je izkazal za najpomembnejši prediktor vrednosti $\mathrm{CO}_{2}$. Druge spremenljivke, kot so $\mathrm{CO}_{2} \mathrm{v}$ prsti in temperaturni gradienti so se izkazale za manj pomembne. Raziskovali smo tudi neprave povezave, pri čemer smo vzeli zunanjo temperaturo kot prediktor koncentracij $\mathrm{CO}_{2}$ v jamah.

Ključne besede: ogljikov dioksid, jama, korelacija, regresijska analiza, prst, lažne povezave, Češka republika.

\section{INTRODUCTION}

Carbon dioxide plays a key role in karst processes such as limestone dissolution and calcite speleothem growth (Dreybrodt 1999). In general, $\mathrm{CO}_{2}$ levels correspond to a steady state, where $\mathrm{CO}_{2}$ fluxes into the system are balanced by fluxes out of the system. Soil $\mathrm{CO}_{2}$ concentrations vary between 0.1 and 10\% vol. (Miotke 1974; Tro- ester \& White 1984). Soil input flux results from organic matter decomposition and root exhalation (Brovkin et al. 2008; Kuzyakov 2006). Output flux is composed from the flux into the outdoor atmosphere by diffusion (Longdoz et al. 2008) and the flux into percolating waters via dissolution (Kaufmann \& Dreybrodt 2007). Soil $\mathrm{CO}_{2}$ shows

\footnotetext{
${ }^{1}$ Department of Geological Sciences, Faculty of Sciences, Masaryk University, Kotlářská 2, 61137 Brno, Czech Republic, email: faimon@sci.muni.cz

${ }^{2}$ Institute of Geological Engineering, Faculty of Mining and Geology, VŠB - Technical University of Ostrava, 17.listopadu 15, 70833 Ostrava - Poruba, Czech Republic, email: monika.licbinska@vsb.cz
} 
strong seasonal fluctuations (Spötl et al. 2005). Epikarst $\mathrm{CO}_{2}$ as an alternative source seems to be relatively invariant (Fairchild et al. 2006).

Cave $\mathrm{CO}_{2}$ shows seasonal variations similarly to soil (Troester \& White 1984; Bourges et al. 2001; Spötl et al. 2005). Common cave $\mathrm{CO}_{2}$ concentrations vary between 0.1 and 1.0\% vol. (Tatár et al. 2004; Baldini et al. 2006). However, higher levels were also monitored in some caves (Atkinson 1977; Ek \& Gewelt 1985). Cave input flux includes (1) natural fluxes, i.e. the fluxes derived from direct diffusion from soil/epikarst or dripwater degassing (Holland et al. 1964) and (2) anthropo- genic flux, i.e. the flux stemming from a person exhaling (Faimon et al. 2006). Output flux is controlled by ventilation, which is given by the cave geometry and pressure/temperature gradients between the cave and the exterior (Spötl et al. 2005; Faimon et al. 2006). When input fluxes increase, cave $\mathrm{P}_{\mathrm{CO} 2}$ increases and the driving force of speleothem growth reduces. In contrast, increasing output flux induces a decrease in cave $\mathrm{P}_{\mathrm{CO} 2}$ and, thus, an increase in the driving forces. The main goal of the study was to test (1) $\mathrm{CO}_{2}$ production in karst soil under different vegetation and (2) its impact on cave $\mathrm{CO}_{2}$.

\section{SITE OF STUDY}

The Moravian Karst is the most extensive karstic area of the Czech Republic (Balák 1999). It covers an area of $94 \mathrm{~km}^{2}$ as a belt $3-5 \mathrm{~km}$ wide and $25 \mathrm{~km}$ long. The alti- tude of the karst plateau varies between $250 \mathrm{~m}$ and $600 \mathrm{~m}$ asl. The granitoid rocks of the Brno Crystalline Massif (Proterozoic) form a crystalline basement. Limestones of the Macocha Formation of the Middle/Upper Devonian period are typical karst rocks (calcite content varies from 95 to $99 \% \mathrm{wt}$ ). Total rock thickness is $500-1000 \mathrm{~m}$. Annual precipitation and temperatures are about $650 \mathrm{~mm}$ and $10^{\circ} \mathrm{C}$, respectively. A sketch map of the monitoring sites is shown in Fig. 1.

\section{SOILS}

Grey rendzic Leptosols are typical for coniferous forests on the Macocha Plateau above the Punkevní Caves (S1-P) and the Sloup sites above the Sloup-Šošůvka Caves (S1-S). Brown rendzic Leptosols make up the decid-

Fig. 1: Sketch map of the monitoring sites. a) Details of SloupŠošùvka Caves and b) Punkevní Caves. For explanation of the abbreviations, see Tab. 1 and Tab. 2. 
Tab. 1: Soil monitoring sites.

\begin{tabular}{lccccc}
\hline code & site & detailed & $\begin{array}{c}\text { soil type } \\
\text { (IUSS Working Group WRB 2006) }\end{array}$ & $\begin{array}{c}\text { PD } \\
{[m]}\end{array}$ & $\begin{array}{c}\text { spatially associated } \\
\text { with }\end{array}$ \\
\hline S1-P & Macocha Plateau & coniferous forest soil & grey rendzic Leptosol & 0.8 & C3-P, C4-P \\
S2-P & Macocha Plateau & deciduous forest soil & mull rendzic Leptosol & 0.3 & C1-P, C2-P, C3-P \\
S1-S & Sloup-Šošůvka & coniferous forest soil & grey rendzic Leptosol & 0.6 & C3-S, C2-S \\
S2-S & Sloup-Šošůvka & deciduous forest soil & brown rendzic Leptosol & 0.5 & C1-S, C2-S \\
\hline
\end{tabular}

(a) soil profile mean depth

Tab. 2: Cave monitoring sites.

\begin{tabular}{lllcccc}
\hline code & Cave & detailed site & $\begin{array}{c}\text { projection } \\
\text { area }\left[\mathrm{m}^{2}\right]\end{array}$ & $\begin{array}{c}\text { volume } \\
{\left[\mathrm{m}^{3}\right]}\end{array}$ & $\begin{array}{c}\text { TO(a) } \\
{[\mathrm{m}]}\end{array}$ & $\begin{array}{c}\text { spatially associated } \\
\text { with }\end{array}$ \\
\hline C1-P & Punkevní C. & Tunnel Corridor & 545 & 3815 & 136 & S2-P \\
C2-P & Punkevní C. & Anděl Chamber & 140 & 1400 & 134 & S2-P \\
C3-P & Punkevní C. & Punkva Sail & 2640 & 10560 & 140 & S1-P, S2-P \\
C4-P & Punkevní C. & Masaryk Hall & 340 & 6120 & 140 & S1-P \\
C1-S & Sloup-Šošůvka C. & Eliška Hall & 915 & 18300 & 72 & S2-S \\
C2-S & Sloup-Šošůvka C. & Chamber above Stupňovitá Abyss & 3430 & 102900 & 51 & S1-S, S2-S \\
C3-S & Sloup-Šošůvka C. & Chamber above Černá Abyss & 550 & 33000 & 50 & $5600^{*}$ \\
\hline
\end{tabular}

(a) thickness of overburden

${ }^{*}$ chamber volume without abyss

uous forest soils above the Sloup-Šošůvka Caves (S2-S). Mull rendzic Leptosols are located in deciduous forest on the Macocha Plateau above the Punkevní Caves (S2-P). A summary of the soil monitoring sites is given in Tab. 1 .

\section{CAVES}

The Punkevni Caves are open to tourists and consist of a complex of chambers, corridors, the Macocha Abyss, and the underground Punkva River. The sites for $\mathrm{CO}_{2}$ monitoring were the Tunnel Corridor (C1-P), the Anděl Speleothem Chamber (C2-P), the Punkva Sail (C3-P) and the Masaryk Hall (C4-P). The Sloup-Šošưvka Caves are open to tourists and form a two-level complex of chambers, corridors and deep abysses. The monitoring sites were the Eliška Hall (C1-S), the Stupňovitá Abyss Chamber (C2-S) and the Černá Abyss Chamber (C3-S). A summary of the cave sites is given in Tab. 2 .

\section{METHODS}

\section{MONITORING}

$\mathrm{CO}_{2}$ concentrations, temperature and humidity were monitored at two-week intervals during the years 2006 2007. Soil monitoring was carried out in probe holes drilled into the soil A-horizon by a steel bar ( $\mathrm{cca} 25 \mathrm{~cm}$, $5 \mathrm{~cm}$ in diameter). The wall of each probe hole was reinforced with a cylinder of polyethylene netting and sealed with a plastic cover. Cave monitoring was accomplished in free atmosphere at a 1-m height above the cave floor.
$\mathrm{CO}_{2}$ concentrations were measured with a handheld device (2-channel A600-CO2H IR-detector FT linked with an ALMEMO 2290-4 V5, Ahlborn, Germany). All the measurements were performed between 10:00 and 16:00, close to the daily maximum.

Relative humidity and temperature were monitored by a digital GFTH 200 hydro/thermometer from Greisinger electronic $\mathrm{GmbH}$, Germany.

External temperature data comes from two weather stations in Lhota u Rapotína and Protivanov. Along a straight line, the stations are about 16 and $18 \mathrm{~km}$ away 
from the study area. The presented data are mean values from both the stations (standard deviation $\sim 0.8^{\circ} \mathrm{C} ; 3.4 \%$ relative deviation).

\section{STATISTICAL ANALYSIS}

All statistical calculations were performed in the Statistica code, Stat Soft. Inc. (Statistica 2010).

\section{Variables}

The monitored/derived variables are distinguished as UVW-Z abbreviations, where U stands for the physical entity/property ( $O$ for carbon dioxide, $T$ for temperature, $d T$ for temperature gradient, $R H$ for relative humidity, $A H$ for absolute humidity, and $A T$ for attendance). The rest of the abbreviation, VW-Z, is consistent with Tabs. 1 and 2. The symbols VW are ignored for attendance, as they are associated with all cave sites. The temperature gradient was assumed either as an absolute value (e.g. $|d T C 1-P|=\mid T C 1-P-T($ ext $) \mid)$ or as a logical value marked with index L (e.g. $d T C 1-P L)$ defined as follows: when $T($ ext $)<T($ cave $)$, then $d T C i-j L=T($ cave $)-T($ ext $)$; when $T($ ext $) \geq T($ cave), then $d T C i-j L=0$.

\section{Outliers}

To detect outliers, Grubbs' test of raw data was conducted at the $\alpha=0.05$ significance level. Only a few outliers were identified, always singly in individual populations (RHS2-P, RHC1-P, RHC2-S, OC3-P, and TC2-S). The outliers were not rejected, as they did not change the results of the data analysis significantly.

\section{Correlation Analysis}

Correlation between the raw data allowed appropriate variables to be selected for subsequent analysis. Based on cross-correlation, the selected variables were tested for a time lag. The weekly data were transformed by linear interpolation into equidistant data with a 15 -day step. Data on cave attendance, available as monthly integral attendance, were recalculated into mean daily data and then transformed by linear interpolation into equidistant data consistent with the former data (with a 15-day step). Based on the found lag, the relevant data were transformed into new data without a lag.

\section{Multicollinearity}

A strong correlation between predictors (multicollinearity) produces redundancy of independent variables in regression analysis. Multicollinearity was assessed using the Variance Inflation Factor (VIF). VIF $>5$ was taken to indicate multicollinearity (Neter et al. 1989; Mayers 1990).

\section{Multiple Linear Regression Analysis}

Multiple Linear Regression Analysis (MLRA) was chosen to find the most significant predictors of the soil/cave $\mathrm{CO}_{2}$-levels. Stepwise Ridge Regression with Backward Elimination was applied (Schmidt \& Muller 1978; Rozeboom 1979).

\section{RESULTS}

\section{SOIL DATA}

The progress of carbon dioxide, humidity, and temperature of the soil atmosphere over one year of monitoring is given in Fig. 2. All the variables were seasonally dependent; the trends in evolution of $\mathrm{CO}_{2}$ and temperature are mutually similar; the trend in relative humidity evolution is opposite (Fig. 2b).

\section{Temperature}

Soil atmosphere temperatures roughly copied outdoor temperatures. They exceeded $30^{\circ} \mathrm{C}$ in some sites in July 2006 and approached $30^{\circ} \mathrm{C}$ in June 2007. The temperature drops below zero at the end of January 2007 (Fig. 2a).

\section{Humidity}

The relative humidity of the soil atmosphere varied between 40 and $85 \%$. Minima were registered in the summer months (July 2006 and August 2007). An extensive maximum is obvious during the monitoring period, from August 2006 to May 2007. A shallow local minimum is presented in January 2007 (Fig. 2b).

\section{Carbon dioxide}

Maxima of carbon dioxide concentrations (between 0.4 and $0.5 \%$ vol.) were registered during the late summer/ early fall months (September and October). The highest carbon dioxide concentrations were systematically monitored during summer/early fall (June to September). Minima (about 0.1 to $0.2 \%$ vol.) were recorded during the winter/early spring months (December to March). The 

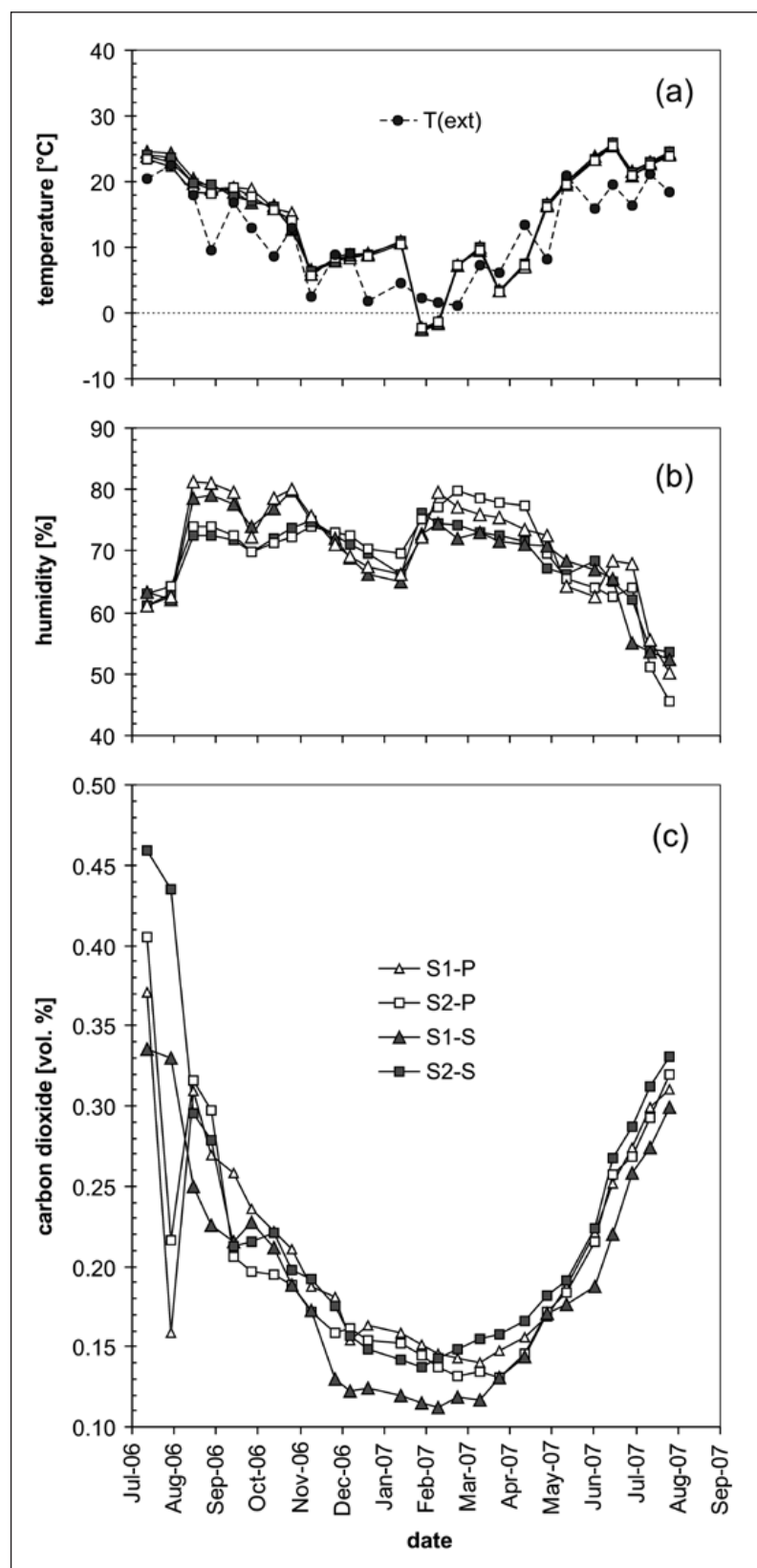

Fig. 2: Soil atmosphere: the progress of a) temperature, b) humidity, and c) carbon dioxide concentration during one year of monitoring. For explanation of the abbreviations, see Tab. 1 and Tab. 2.

lowest carbon dioxide concentrations were registered in coniferous forest soils (S1-P) during winter (Fig. 2c).

\section{CAVE DATA}

Cave $\mathrm{CO}_{2}$ data are highly seasonally dependent. In contrast, cave humidity is less dependent, and temperature is almost conserved in most of the caves (Fig. 3).

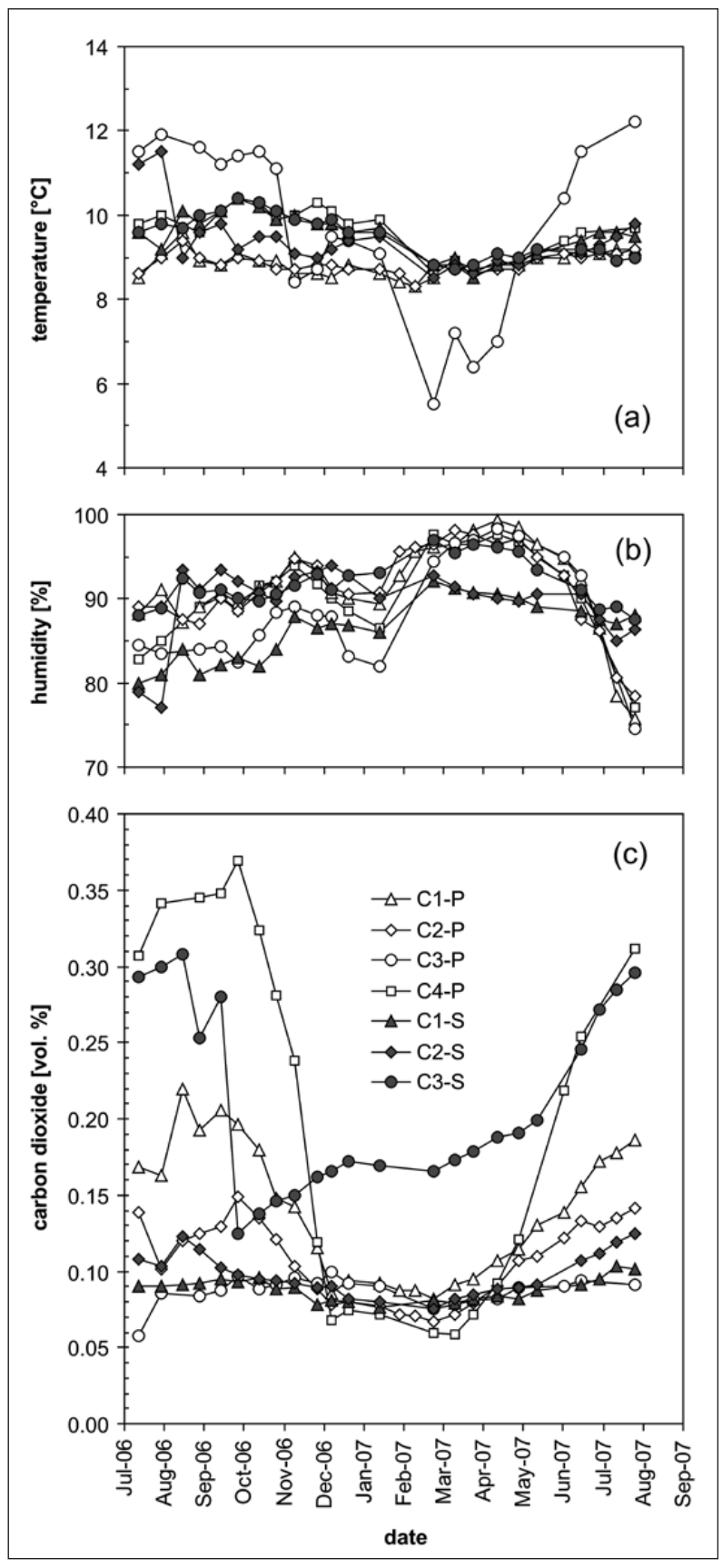

Fig. 3: Cave atmosphere: the progress of a) temperature, b) humidity, and c) carbon dioxide concentration during one year of monitoring. For explanation of the abbreviations, see Tab. 1 and Tab. 2.

\section{Temperature}

Cave temperatures remained almost constant during the year. Depending on locality, temperatures were between 8 and $14^{\circ} \mathrm{C}$. Only the Punkva Sail site (C3-P) showed larger seasonal variations, from 5 to $13^{\circ} \mathrm{C}$ (Fig. 3a). 


\section{Humidity}

Cave humidity shows similar seasonal trends as soil humidity, however, less obvious. Minima were registered in the summer months (July), maxima are in the winter/spring months (February 2007 to May 2007). A local minimum is visible in January 2007 similarly to soils (Fig. 3b).

\section{Carbon dioxide}

Maxima of carbon dioxide concentrations (between 0.3 and $0.4 \%$ vol.) were recorded during late summer/early fall (August to September). Minima (about 0.1\% vol.) were recorded during winter/early spring (December to April). During the period, somewhat enhanced concentrations (up to $0.19 \%$ vol.) were achieved in the Černá Abyss (C3-S). The largest seasonal variations were registered in the Masaryk Dóm Chamber (C4-P). In contrast, only slight variations were found in the Punkva Sail (C3-P), Anděl Dóm Chamber (C2-P), Stupňovitá Abyss (C2-S), and the Eliška Dóm Chamber (C1-S) (Fig. 3c).

\section{DATA ANALYSIS}

\section{RAW DATA CORRELATIONS}

\section{Soils}

Positive correlations were found between all the soil variables except for relative humidity. For individual soils, strong correlations are found between absolute humidity and temperature $(r>0.9), \mathrm{CO}_{2}$ concentrations and temperature, and $\mathrm{CO}_{2}$ concentrations and absolute humidity ( $r \sim 0.74$ to 0.83 ). $(\mathrm{r} \sim 0.66$ to 0.86$)$. Important correlations are given in Tab. 3. All correlations are significant at $\alpha<0.05$.

\section{Punkevní Caves}

In the $\mathrm{C} 1-\mathrm{P}, \mathrm{C} 2-\mathrm{P}$, and $\mathrm{C} 4-\mathrm{P}$ sites, $\mathrm{CO}_{2}$ levels are positively correlated with the soil $\mathrm{CO}_{2}$ concentrations $(\mathrm{r} \sim 0.74$ to 0.85 ), attendance ( $r \sim 0.74$ to 0.77 ), and external temperature ( $\mathrm{r} \sim 0.68$ to 0.72 ). The correlations with absolute value of temperature gradient are insignificant $(r \sim 0.22$

Tab. 3: Correlation matrix: Macocha Plateau and Sloup-Šošůvka soils.

\begin{tabular}{|c|c|c|c|c|c|c|c|c|c|c|c|c|c|}
\hline & $\frac{a}{\grave{\Lambda}}$ & $\frac{a}{n}$ & $\frac{a}{\frac{1}{n}}$ & ¿ิે & 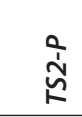 & 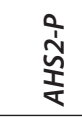 & $\frac{\tilde{1}}{\tilde{\nu}}$ & $\frac{\tilde{n}}{\tilde{n}}$ & $\frac{n}{\frac{n}{\alpha}}$ & $\begin{array}{l}\tilde{\tilde{U}} \\
\widetilde{0}\end{array}$ & $\stackrel{\tilde{\aleph}}{\tilde{\kappa}}$ & 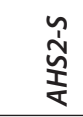 & $\begin{array}{l}\overrightarrow{\widetilde{v}} \\
\stackrel{2}{N}\end{array}$ \\
\hline OS1-P & 1.00 & & & & & & & & & & & & \\
\hline TS1-P & 0.74 & 1.00 & & & & & & & & & & & \\
\hline$A H S 1-P$ & 0.74 & 0.95 & 1.00 & & & & & & & & & & \\
\hline OS2-P & 0.95 & 0.76 & 0.74 & 1.00 & & & & & & & & & \\
\hline$T S 2-P$ & 0.74 & 1.00 & 0.96 & 0.76 & 1.00 & & & & & & & & \\
\hline$A H S 2-P$ & 0.71 & 0.95 & 0.99 & 0.74 & 0.96 & 1.00 & & & & & & & \\
\hline OST-S & 0.81 & 0.82 & 0.78 & 0.87 & 0.83 & 0.79 & 1.00 & & & & & & \\
\hline TS1-S & 0.74 & 1.00 & 0.95 & 0.77 & 1.00 & 0.95 & 0.83 & 1.00 & & & & & \\
\hline AHS1-S & 0.73 & 0.95 & 0.98 & 0.76 & 0.96 & 0.99 & 0.79 & 0.96 & 1.00 & & & & \\
\hline OS2-S & 0.74 & 0.75 & 0.71 & 0.87 & 0.75 & 0.74 & 0.96 & 0.77 & 0.74 & 1.00 & & & \\
\hline TS2-S & 0.74 & 1.00 & 0.95 & 0.77 & 1.00 & 0.96 & 0.84 & 1.00 & 0.96 & 0.78 & 1.00 & & \\
\hline$A H S 2-S$ & 0.72 & 0.96 & 0.98 & 0.76 & 0.97 & 0.98 & 0.81 & 0.97 & 0.99 & 0.77 & 0.97 & 1.00 & \\
\hline$T(e x t)$ & 0.66 & 0.86 & 0.82 & 0.70 & 0.86 & 0.83 & 0.81 & 0.86 & 0.83 & 0.76 & 0.86 & 0.85 & 1.00 \\
\hline
\end{tabular}

In addition, strong correlations are found between the same quantities in different soils and even different sites (the Macocha Plateau and Sloup-Šošůvka sites). This is the case for $\mathrm{CO}_{2}$ concentrations ( $\mathrm{r} \sim 0.74$ to 0.95$)$, temperature $(\mathrm{r} \sim 1)$, and absolute humidity $(\mathrm{r} \sim 0.98$ to $0.99)$. All variables correlate with external temperature to 0.31 ). In turn, the correlations with logical temperature gradients are stronger and negative $(\mathrm{r} \sim-0.59$ to -0.67$)$. The cave $\mathrm{CO}_{2}$ levels are strongly correlated with each other between different sites ( $\mathrm{r} \sim 0.90$ to 0.97 ), except for site 3 . In site 3 , the correlations of all variables are quite insignificant $(r \sim-0.24$ to 0.15$)$. Important correlations 
Tab. 4: Correlation matrix: Punkevní Caves.

\begin{tabular}{|c|c|c|c|c|c|c|c|c|c|c|c|c|c|c|c|c|}
\hline & $\frac{0}{\frac{1}{n}}$ & $\begin{array}{l}\text { ஸे } \\
\text { ปิ }\end{array}$ & $\frac{\hat{1}}{\grave{0}}$ & $\begin{array}{l}\bar{a} \\
\frac{1}{v} \\
\frac{0}{\sigma}\end{array}$ & $\frac{a}{\vdots}$ & $\begin{array}{l}\stackrel{\leftrightarrow}{\sim} \\
\text { ஸे }\end{array}$ & $\begin{array}{l}\overline{\mathbf{a}} \\
\text { 웜 } \\
\text { 으 }\end{array}$ & 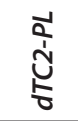 & $\begin{array}{l}\hat{i} \\
\hat{O}\end{array}$ & $\begin{array}{l}\bar{a} \\
\stackrel{0}{0} \\
\underline{0}\end{array}$ & 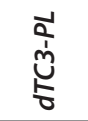 & $\begin{array}{l}\frac{a}{1} \\
\text { ঠ̀ } \\
\text { d }\end{array}$ & $\begin{array}{l}\bar{a} \\
\dot{d} \\
\underline{0} \\
\underline{0}\end{array}$ & 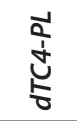 & 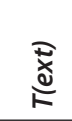 & $\frac{0}{\frac{1}{\alpha}}$ \\
\hline OS1-P & 1.00 & & & & & & & & & & & & & & & \\
\hline OS2-P & 0.95 & 1.00 & & & & & & & & & & & & & & \\
\hline$O C 1-P$ & 0.83 & 0.76 & 1.00 & & & & & & & & & & & & & \\
\hline$|d T C 1-P|$ & 0.41 & 0.48 & 0.31 & 1.00 & & & & & & & & & & & & \\
\hline$d T C 1-P L$ & -0.52 & -0.51 & -0.60 & 0.00 & 1.00 & & & & & & & & & & & \\
\hline$O C 2-P$ & 0.85 & 0.76 & 0.90 & 0.29 & -0.67 & 1.00 & & & & & & & & & & \\
\hline$|d T C 2-P|$ & 0.40 & 0.47 & 0.31 & 1.00 & 0.01 & 0.29 & 1.00 & & & & & & & & & \\
\hline$d T C 2-P L$ & -0.52 & -0.51 & -0.60 & 0.00 & 1.00 & -0.67 & 0.01 & 1.00 & & & & & & & & \\
\hline OC3-P & -0.15 & -0.24 & 0.10 & -0.20 & -0.14 & 0.15 & -0.21 & -0.15 & 1.00 & & & & & & & \\
\hline$|d T C 3-P|$ & 0.31 & 0.40 & 0.24 & 0.92 & 0.05 & 0.23 & 0.92 & 0.04 & -0.15 & 1.00 & & & & & & \\
\hline dTC3-PL & -0.42 & -0.41 & -0.45 & -0.08 & 0.92 & -0.51 & -0.08 & 0.91 & 0.00 & 0.07 & 1.00 & & & & & \\
\hline OC4-P & 0.78 & 0.74 & 0.97 & 0.34 & -0.58 & 0.90 & 0.34 & -0.58 & 0.10 & 0.27 & -0.42 & 1.00 & & & & \\
\hline$|d T C 4-P|$ & 0.31 & 0.39 & 0.20 & 0.98 & 0.14 & 0.17 & 0.98 & 0.14 & -0.17 & 0.94 & 0.07 & 0.22 & 1.00 & & & \\
\hline dTC4-PL & -0.54 & -0.54 & -0.62 & -0.08 & 0.99 & -0.68 & -0.07 & 0.99 & -0.08 & 0.00 & 0.94 & -0.59 & 0.07 & 1.00 & & \\
\hline$T(e x t)$ & 0.66 & 0.70 & 0.68 & 0.59 & -0.80 & 0.72 & 0.59 & -0.80 & 0.01 & 0.51 & -0.78 & 0.68 & 0.47 & -0.84 & 1.00 & \\
\hline$A T-P$ & 0.78 & 0.84 & 0.76 & 0.59 & -0.66 & 0.77 & 0.58 & -0.66 & -0.09 & 0.52 & -0.61 & 0.74 & 0.48 & -0.72 & 0.89 & 1.00 \\
\hline
\end{tabular}

are summarized in Tab. 4. The correlations significant at $a<0.05$ are highlighted.

\section{Sloup-Šošuvka Caves}

The $\mathrm{CO}_{2}$ concentrations in the Sloup-Šošůvka Cave sites are positively correlated with the soil concentrations ( $r \sim 0.66$ to 0.85 ), external temperature $(r \sim 0.69$ to 0.77 ), and attendance $(\mathrm{r} \sim 0.76$ to 0.91$)$. Insignificant or weak correlations are found between $\mathrm{CO}_{2}$ levels and absolute temperature gradients $(\mathrm{r} \sim 0.33$ to 0.59$)$. Negative correlations are found between the $\mathrm{CO}_{2}$ levels and logical tem- perature gradients $(\mathrm{r} \sim-0.49$ to -0.66$)$. Similarly to the Punkevní Caves, $\mathrm{CO}_{2}$ concentrations themselves strongly correlate between adjacent parts of the cave system ( $\mathrm{r} \sim 0.80$ to 0.86 ), but less strongly between non-adjacent sites $(r \sim 0.59)$. Important correlations are given in Tab. 5 . The correlations significant at $\alpha<0.05$ are highlighted.

\section{CROSS-CORRELATION OF EQUIDISTANT DATA} The equidistant data on soil $\mathrm{CO}_{2}$ levels were cross-correlated with those on soil temperature $(T)$, relative/absolute humidity $(R H / A H)$, and external temperature $\left(T_{(\mathrm{ext})}\right)$.

Tab. 5: Correlation matrix: Sloup-Šošůvka Caves.

\begin{tabular}{|c|c|c|c|c|c|c|c|c|c|c|c|c|c|}
\hline & $\frac{n}{\tilde{n}}$ & นิ่ & ธิ & $\begin{array}{l}\bar{n} \\
\frac{1}{5} \\
\underline{\sigma}\end{array}$ & $\begin{array}{l}\vec{n} \\
\frac{1}{5}\end{array}$ & ஸ્. & $\begin{array}{l}\overline{\tilde{\Lambda}} \\
\stackrel{\tilde{\sigma}}{\sigma}\end{array}$ & 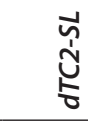 & $\tilde{\text { ஸे }}$ & $\begin{array}{l}\overline{\hat{n}} \\
\stackrel{0}{0} \\
\underline{0}\end{array}$ & 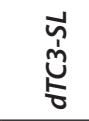 & 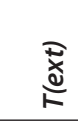 & 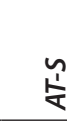 \\
\hline OS1-S & 1.00 & & & & & & & & & & & & \\
\hline OS2-S & 0.96 & 1.00 & & & & & & & & & & & \\
\hline OC1-S & 0.82 & 0.66 & 1.00 & & & & & & & & & & \\
\hline$|d T C 1-S|$ & 0.49 & 0.52 & 0.33 & 1.00 & & & & & & & & & \\
\hline$d T C 1-S L$ & -0.60 & -0.53 & -0.56 & 0.08 & 1.00 & & & & & & & & \\
\hline$O C 2-S$ & 0.85 & 0.78 & 0.86 & 0.30 & -0.67 & 1.00 & & & & & & & \\
\hline$|d T C 2-S|$ & 0.47 & 0.47 & 0.37 & 0.98 & 0.05 & 0.34 & 1.00 & & & & & & \\
\hline$d T C 2-S L$ & -0.58 & -0.52 & -0.55 & 0.11 & 1.00 & -0.66 & 0.09 & 1.00 & & & & & \\
\hline OC3-S & 0.77 & 0.80 & 0.59 & 0.57 & -0.49 & 0.80 & 0.56 & -0.46 & 1.00 & & & & \\
\hline$|d T C 3-S|$ & 0.50 & 0.53 & 0.37 & 1.00 & 0.06 & 0.34 & 0.99 & 0.10 & 0.59 & 1.00 & & & \\
\hline$d T C 3-S L$ & -0.60 & -0.53 & -0.55 & 0.07 & 1.00 & -0.67 & 0.04 & 1.00 & -0.49 & 0.05 & 1.00 & & \\
\hline$T(e x t)$ & 0.81 & 0.76 & 0.69 & 0.48 & -0.83 & 0.77 & 0.50 & -0.81 & 0.74 & 0.49 & -0.84 & 1.00 & \\
\hline AT-S & 0.91 & 0.89 & 0.76 & 0.51 & -0.63 & 0.91 & 0.52 & -0.61 & 0.91 & 0.54 & -0.63 & 0.84 & 1.00 \\
\hline
\end{tabular}


The results are presented in Tab. 6. All time lags are zero, except for OS1-P, which lags after soil absolute humidity and external temperature (both lags $\sim 2$ ).

The cave $\mathrm{CO}_{2}$ concentrations were cross-correlated with attendance, logical temperature gradients, and soil $\mathrm{CO}_{2}$ levels. The results are given in Tab. 7. Time lags vary from -1 (where the lagging variable follows the first variable) to an extreme of 5 (where the lagged variables precede the first variable). Whereas cave $\mathrm{CO}_{2}$ levels do not significantly lag behind soil levels (except for the pair OC1-P/OS2-P), the logical temperature gradient precedes the cave $\mathrm{CO}_{2}$ levels (except for the pair OC3-S/dTC3-S). The $\mathrm{CO}_{2}$ levels in the Punkevní Cave sites lag after attendance by lag $\sim 2$, except for the extreme lag $\sim 5$ at site 3 . In the Sloup-Šošůvka Cave sites, the attendance is without any lag.

Tab. 6: Time lag of selected variables against soil $\mathrm{CO}_{2}$ concentrations.

\begin{tabular}{lcccc}
\hline & \multicolumn{4}{c}{ first (dependent) variable } \\
\cline { 2 - 5 } $\begin{array}{l}\text { lagged independent } \\
\text { variable }\end{array}$ & OS1-P & OS2-P & OS1-S & OS2-S \\
\hline soil temperature & 0 & 0 & 0 & 0 \\
soil relative humidity & 0 & 0 & 0 & 0 \\
soil absolute humidity & 2 & 0 & 0 & 0 \\
external temperature & 2 & 0 & 0 & 0 \\
\hline
\end{tabular}

j stands for relevant environment $\mathrm{P}$ or $\mathrm{S}$; i stands for relevant sites 1 to 2

lag $\sim 1$ corresponds to 15-day step

\section{Soils}

Both soil air temperature (sites OS1-P, OS2-P, and OS1-S) and absolute humidity (sites OS1-P, OS2-S) appear to be the best predictors of soil $\mathrm{CO}_{2}$ concentrations. For site OS1-P, the effect of both lag-transformed predictors were distinguished. In this case, temperature and humidity explain the soil $\mathrm{CO}_{2}$ by 38 and $60 \%$, respectively. Alternatively, linear models with external temperature as an alternative predictor were derived (Tab. 9). All models are statistically significant.

\section{Caves}

Almost all models indicate visitor attendance as the most significant predictor of cave $\mathrm{CO}_{2}$ levels. This is the case for the Punkevní Caves except for site C2-P, where the untransformed soil $\mathrm{CO}_{2}$ and temperature gradient are predictors. For site $\mathrm{C} 1-\mathrm{P}$, soil $\mathrm{CO}_{2}$ is an additional predictor to attendance. The attendance is the sole predictor at sites C3-P and C4-P, although the former model is less significant.

In the case of the Sloup-Šošůvka Caves, attendance is the sole predictor in all the models in which untransformed data were used. In the case of lag-transformed data, both temperature gradient and soil $\mathrm{CO}_{2}$ are significant variables for site $\mathrm{C} 1-\mathrm{S}$. The soil $\mathrm{CO}_{2}$ is an additional predictor together with attendance for site $\mathrm{C} 2-\mathrm{S}$.

\section{LINEAR REGRESSION}

Linear models of soil/cave $\mathrm{CO}_{2}$ levels with the external temperature as a unique predictor were derived (Tab. 9).

Tab. 7: Time lag of selected variables against cave $\mathrm{CO}_{2}$ concentrations.

\begin{tabular}{lccccccc}
\hline & \multicolumn{7}{c}{ first (dependent) variable } \\
\cline { 2 - 8 } lagged independent variable & OC1- $P$ & OC2-P & OC3- $P$ & OC4- $P$ & OC1-S & OC2-S & OC3-S \\
\hline cave attendance & 2 & 2 & 5 & 2 & 0 & 0 & 0 \\
temperature gradient (logical) & 2 & 2 & 5 & 2 & 2 & 1 & -1 \\
soil $\mathrm{CO}_{2}$ (coniferous) & 0 & 0 & 0 & 0 & 0 & 0 & 0 \\
soil $\mathrm{CO}_{2}$ (deciduous) & 1 & 0 & 0 & 0 & 0 & 0 & 0 \\
\hline
\end{tabular}

i stands for relevant sites 1 to 4

$\mathrm{j}$ stands for relevant environment $\mathrm{P}$ or $\mathrm{S}$

lag $\sim 1$ corresponds to 15-day step

\section{REGRESSION ANALYSIS}

The Multiple Linear Regression Analysis (MLRA) was conducted separately for the data for which the time lag was accepted (transformed data) versus unaccepted (raw data without any transformation). All significant models are presented in Tab. 8. The terms in regression equations with $p$-values exceeding 0.05 are mentioned in the notes. The models that were physically inappropriate, e.g. those including a term with an illogical sign, were rejected.
Except for $O C 3-P$, all models are significant at $\alpha<0.05$ and show that external temperature explains the $\mathrm{CO}_{2}$ levels by 68 to $77 \%$.

\section{ESTIMATION OF ANTHROPOGENIC $\mathrm{CO}_{2}$ CONTENT IN CAVE $\mathrm{CO}_{2}$}

Based on (1) monthly attendance, (2) visiting period at individual sites, (3) cave site volumes, and (4) exhaled $\mathrm{CO}_{2}$ (15 L of exhaled air per minute per person; $5 \%$ vol. 
Tab. 8: Multiple linear regression analysis (stepwise ridge regression).

\begin{tabular}{|c|c|c|c|c|c|c|c|c|}
\hline \multirow[b]{2}{*}{$\begin{array}{l}\text { dependent } \\
\text { variable }\end{array}$} & \multicolumn{4}{|l|}{ model } & \multicolumn{3}{|c|}{ beta coefficients } & \multirow[b]{2}{*}{ notes } \\
\hline & equation & $d f$ & F-value & $R^{2}$ & p-value & $\begin{array}{c}\text { I. } \\
\text { variable }\end{array}$ & $\begin{array}{c}\text { II. } \\
\text { variable }\end{array}$ & \\
\hline & \multicolumn{7}{|c|}{ cave $\mathrm{CO}_{2}$} & \\
\hline \multirow[t]{2}{*}{$O C 1-P$} & $O C 1-P=0.0681+0.000036 A T-P^{(a)}+0.2294$ OS2- $P^{(b)}$ & $2 / 23$ & 16.8 & 0.59 & $<0.001$ & 0.41 & 0.38 & $\mathrm{nLa}$ \\
\hline & $O C 1-P=0.0841+0.000086 A T-P$ & $1 / 22$ & 137.9 & 0.86 & $<0.001$ & 0.89 & $\mathrm{n}$ & La \\
\hline \multirow[t]{2}{*}{$O C 2-P$} & $O C 2-P=0.0727+0.1929$ OS2 $-P-0.00348 d T C 2-P L$ & $2 / 23$ & 20.7 & 0.64 & $<0.001$ & 0.52 & -0.36 & $\mathrm{nLa}$ \\
\hline & $O C 2-P=0.0758+0.000048 A T-P$ & $1 / 22$ & 74.3 & 0.77 & $<0.001$ & 0.84 & $\mathrm{n}$ & La \\
\hline \multirow[t]{2}{*}{ OC3-P } & No model & $\mathrm{n}$ & $\mathrm{n}$ & $\mathrm{n}$ & $\mathrm{n}$ & $\mathrm{n}$ & $\mathrm{n}$ & $\mathrm{nLa}$ \\
\hline & $O C 3-P=0.0838+0.000008$ AT- $P$ & $1 / 19$ & 11.9 & 0.38 & 0.003 & 0.59 & $\mathrm{n}$ & La \\
\hline \multirow[t]{2}{*}{$O C 4-P$} & $O C 4-P=0.0953+0.000162 A T-P$ & $1 / 24$ & 23.9 & 0.50 & $<0.001$ & 0.67 & $\mathrm{n}$ & $\mathrm{nLa}$ \\
\hline & $O C 4-P=0.0561+0.000219 A T-P$ & $1 / 22$ & 110.1 & 0.83 & $<0.001$ & 0.87 & $\mathrm{n}$ & La \\
\hline \multirow[t]{2}{*}{ OC1-S } & $O C 1-S=0.0820+0.000029 A T-S$ & $1 / 24$ & 26.8 & 0.53 & $<0.001$ & 0.69 & $\mathrm{n}$ & $\mathrm{nLa}$ \\
\hline & $O C 1-S=0.0701-0.000548 d T C 1-S L+0.0890$ OS2-S & $2 / 21$ & 39.1 & 0.79 & $<0.001$ & -0.25 & 0.69 & La \\
\hline \multirow[t]{2}{*}{$O C 2-S$} & $O C 2-S=0.0837+0.000068 A T-S$ & $1 / 24$ & 75.7 & 0.75 & $<0.001$ & 0.83 & $\mathrm{n}$ & $\mathrm{nLa}$ \\
\hline & $O C 2-S=0.0723+0.000044 A T-S+0.0827 O S 1-S$ & $2 / 22$ & 52.8 & 0.83 & $<0.001$ & 0.54 & 0.36 & La \\
\hline \multirow[t]{3}{*}{ OC3-S } & $O C 3-S=0.1581+0.002750 A T-S$ & $1 / 24$ & 74.9 & 0.75 & $<0.001$ & 0.83 & $\mathrm{n}$ & $\mathrm{nLa}$ \\
\hline & $O C 3-S=0.1574+0.000275 A T-S$ & $1 / 23$ & 70.8 & 0.75 & $<0.001$ & 0.83 & $\mathrm{n}$ & La \\
\hline & & $\mathrm{CO}_{2}$ & & & & & & \\
\hline \multirow[t]{2}{*}{ OS1-P } & $O S 1-P=0.1003+0.01203$ AHS1-P & $1 / 24$ & 23,6 & 0,50 & $<0.001$ & 0.67 & $\mathrm{n}$ & $\mathrm{nLa}$ \\
\hline & OS1 $-P=0.0831+0.00279$ TS1-P +0.00943 AHS1-P & $2 / 21$ & 59.1 & 0.85 & $<0.001$ & 0.38 & 0.60 & La \\
\hline OS2-P & OS2-P $=0.1180+0.00611$ TS2-P & $1 / 24$ & 27.0 & 0.53 & $<0.001$ & 0.69 & $\mathrm{n}$ & $\mathrm{nL}$ \\
\hline OS1-S & OS1-S $=0.1017+0.00627$ TS1-S & $1 / 24$ & 40.3 & 0.63 & $<0.001$ & 0.75 & $\mathrm{n}$ & $\mathrm{nL}$ \\
\hline OS2-S & OS2-S $=0.0733+0.01656$ AHS2-S & $1 / 24$ & 28.1 & 0.54 & $<0.001$ & 0.70 & $\mathrm{n}$ & $\mathrm{nL}$ \\
\hline
\end{tabular}

${ }^{(a)} \mathrm{p}=0.051 ;{ }^{(\mathrm{b})} \mathrm{p}=0.069$

df - degree of freedom; $n$ - not relevant

Beta-coefficient indicates relative weight of single independent variable for prediction of dependent variable notes: $\mathrm{nL}$ - no lag; nLa - no lag accepted; La - lag accepted

Tab. 9: Linear regression analysis: soil/cave $\mathrm{CO}_{2}$ vs. external temperature.

\begin{tabular}{lccccccccc}
\hline & \multicolumn{3}{c}{ model } & \multicolumn{5}{c}{ regression coefficient } \\
\cline { 2 - 11 } & $\boldsymbol{d f}$ & $\boldsymbol{F}$-value & $\boldsymbol{R}^{2}$ & $\boldsymbol{p}$-value & $\boldsymbol{b}_{0}$ & $\boldsymbol{p}$-value & $\boldsymbol{b}_{1}$ & $\boldsymbol{p}$-value & $\boldsymbol{b}$ beta \\
\hline OS1-P & $1 / 24$ & 19.0 & 0.44 & $<0.001$ & 0.1392 & $<0.001$ & 0.00142 & $<0.001$ & 0.66 \\
OS2-P & $1 / 24$ & 23.0 & 0.49 & $<0.001$ & 0.1224 & $<0.001$ & 0.00722 & $<0.001$ & 0.70 \\
OS1-S & $1 / 24$ & 45.1 & 0.65 & $<0.001$ & 0.0989 & $<0.001$ & 0.00799 & $<0.001$ & 0.81 \\
OS2-S & $1 / 24$ & 35.6 & 0.60 & $<0.001$ & 0.0776 & $<0.001$ & 0.00160 & $<0.001$ & 0.77 \\
OC1-P & $1 / 24$ & 20.6 & 0.46 & $<0.001$ & 0.0900 & $<0.001$ & 0.00427 & $<0.001$ & 0.68 \\
OC2-P & $1 / 24$ & 25.5 & 0.52 & $<0.001$ & 0.0752 & $<0.001$ & 0.00272 & $<0.001$ & 0.72 \\
OC3-P & $1 / 24$ & 0.0 & 0.00 & 0.980 & 0.0870 & $<0.001$ & 0.00007 & 0.980 & 0.01 \\
OC4-P & $1 / 24$ & 20.2 & 0.46 & $<0.001$ & 0.0711 & 0.048 & 0.01140 & $<0.001$ & 0.68 \\
OC1-S & $1 / 24$ & 22.4 & 0.48 & $<0.001$ & 0.0021 & $<0.001$ & 0.00074 & $<0.001$ & 0.69 \\
OC2-S & $1 / 24$ & 35.6 & 0.60 & $<0.001$ & 0.0776 & $<0.001$ & 0.00160 & $<0.001$ & 0.77 \\
OC3-S & $1 / 24$ & 29.4 & 0.55 & $<0.001$ & 0.1360 & $<0.001$ & 0.00626 & $<0.001$ & 0.74 \\
\hline
\end{tabular}

of $\mathrm{CO}_{2}$ ), contents of anthropogenic $\mathrm{CO}_{2}$ were estimated for individual cave sites under the assumption that the sites were not ventilated. The results are presented in Fig. 4. as the ratio of hypothetical anthropogenic $\mathrm{CO}_{2}$ concentrations to the actual $\mathrm{CO}_{2}$ concentration. In the Punkevní Caves, the levels of exhaled $\mathrm{CO}_{2}$ should exceed by many times the actual $\mathrm{CO}_{2}$ levels. In contrast, the anthropogenic $\mathrm{CO}_{2}$ levels in the Sloup-Šošůvka Caves show a much lower proportion relative to the actual $\mathrm{CO}_{2}$ concentrations: at sites $\mathrm{C} 2-\mathrm{S}$ and $\mathrm{C} 3-\mathrm{S}$, the anthropogenic $\mathrm{CO}_{2}$ would not cover the actual levels. 


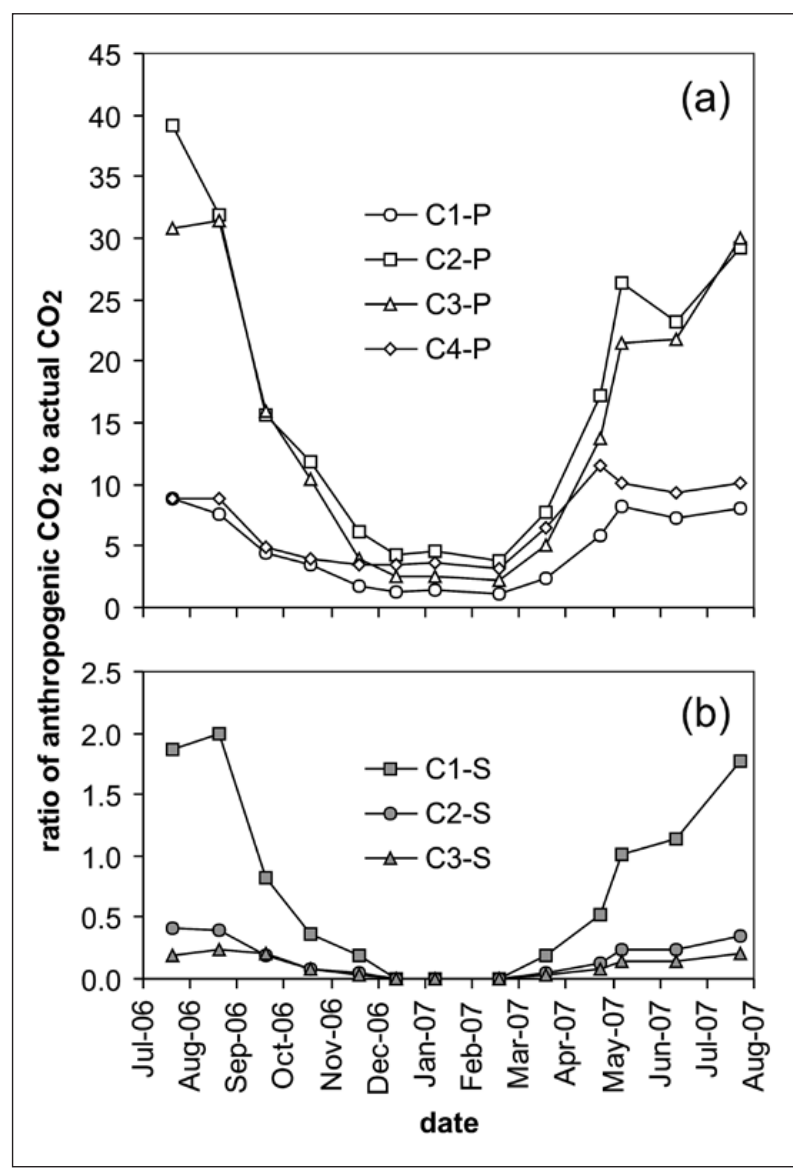

Fig. 4: The ratio of hypothetical anthropogenic $\mathrm{CO}_{2}$ concentrations to the actual $\mathrm{CO}_{2}$ concentration in a) the Punkevni Caves and b) Sloup-Šošùvka Caves. For explanation of the abbreviations, see Tab. 1 and Tab. 2.

\section{DISCUSSION}

\section{Soil $\mathrm{CO}_{2}$}

The observed soil $\mathrm{CO}_{2}$ levels up to $1 \%$ vol. are in the range found by others (Zhang et al. 2005). The data analysis confirmed that soil $\mathrm{CO}_{2}$ concentrations are controlled by soil temperature and humidity. This is consistent with the findings of other authors (Jassal et al. 2004; Iqbal et al. 2008). Both quantities are strongly interrelated, which makes it difficult to separate individual effects (Li et al. 2008). MLRA allowed the distinguishing of lag-transformed soil temperature and absolute humidity (the site S1-P), but this distinguishing is based purely on the significance of individual variables.

For a convenient prediction of soil $\mathrm{CO}_{2}$ concentrations, linear models with external temperature as the predictor were designed. Beta coefficients showed that external temperature could explain the soil $\mathrm{CO}_{2}$ levels by 66 to $81 \%$.

The strong correlations of the $\mathrm{CO}_{2}$ concentrations found between different soil types and even between different sites did not confirm the influence of vegetation on soil $\mathrm{CO}_{2}$ production and did moderate the concern about the impact of vegetation on karst processes (e.g. Balák et al. 1999; Bárány-Kevei 1999).

\section{Cave $\mathrm{CO}_{2}$}

The monitored cave $\mathrm{CO}_{2}$ levels are consistent with the values up to $1 \%$ vol. found by many researchers (Baldini et al. 2006, 2008). In comparison to soils, the cave $\mathrm{CO}_{2}$ levels showed greater variability.

One problem with cave $\mathrm{CO}_{2}$ modelling is the time lag of variables. It is obvious that soil $\mathrm{CO}_{2}$ requires a certain period of time in order to reach a given cave. Similarly, cave ventilation associated with the temperature gradient needs some period to exchange the cave atmosphere. Although anthropogenic $\mathrm{CO}_{2}$ appears in the cave immediately, a certain period is needed for $\mathrm{CO}_{2}$ levels to return to their natural state. Faimon et al. (2006) showed that the relaxation time of a well-ventilated cave is about 24 hours. However, this period could be much higher in the case of poorly ventilated caves. The lag $\sim 2$ (corresponding to 30 days) of the attendance in the Punkevní Cave sites C1-P, C2-P, C4-P against cave $\mathrm{CO}_{2}$ is long but perhaps acceptable. In contrast, the lag $\sim 5$ at site C3-P is clearly inconceivable. A data transformation into new data without the lag is a possible approach to identifying the driving variable. Because the resulting regression equations with differently lagged variables are hardly applicable for a convenient cave $\mathrm{CO}_{2}$ level prediction, alternative models based on the original data were derived.

\section{Cave $\mathrm{CO}_{2}$ sources}

Data analysis suggests that the generally accepted belief that soils are the main source of cave $\mathrm{CO}_{2}$ could be questioned. MLRA showed that the soil $\mathrm{CO}_{2}$ levels appeared as predictors in only four models (of thirteen in total) and always combined with another predictor. In these models, the share of soil $\mathrm{CO}_{2}$ in cave $\mathrm{CO}_{2}$ levels varied between 38 and $69 \%$. Doubts about the dominant role of soils in cave $\mathrm{CO}_{2}$ resonate with some authors (Miotke 1974; Bárány-Kevei 1999; Tatár et al. 2004; Baldini et al. 2005). Even if the soil $\mathrm{CO}_{2}$ effect was superimposed by anthropogenic $\mathrm{CO}_{2}$ in this study, alternative sources (e.g. epikarstic sediments) should be considered in future studies.

Attendance was identified as a main predictor of cave $\mathrm{CO}_{2}$ levels in both the caves, which indicates a broad anthropogenic impact. An exception is site C3-P, where no model was found for untransformed data and 
the model for lagged data is physically unacceptable. In this site, the $\mathrm{CO}_{2}$ values are probably controlled by distinct factors despite the MLRA results (see the discussion later). The attendance impact is most obvious in the Sloup-Šošůvka Caves, especially in sites C2-S and C3-S, where the lag of variables is near zero. Paradoxically, based on the estimations of exhaled $\mathrm{CO}_{2}$, the contributions of anthropogenic $\mathrm{CO}_{2}$ levels in these sites should be lowest. The reason for this contradiction may be an overestimation of cave site volumes. Both the sites are linked to abysses lying below the visitor route with a disputable contribution to total site volumes. If the abyss volumes are omitted, the share of anthropogenic $\mathrm{CO}_{2}$ rises to $87 \%$ (C2-S) or above $100 \%$ (C3-S) of actual cave $\mathrm{CO}_{2}$. Despite the clear influence of anthropogenic $\mathrm{CO}_{2}$ on the cave environment, long-term monitoring of dripwaters (in the Punkevní Caves especially) shows permanent water supersaturation (Faimon \& Ličbinská, unpublished data), which indicates that the impact is not destructive. This conclusion is consistent with the study of the anthropogenic $\mathrm{CO}_{2}$ impact in the Císařská Cave (Faimon et al. 2006).

\section{Factors suppressing cave $\mathrm{CO}_{2}$ levels}

It is well known that cave air circulation depends on temperature gradients between the interior and exterior ( $\mathrm{de}$ Freitas et al. 1982; Russell \& McLean 2008). Dynamic caves (see Geiger et al. 2003; Spötl et al. 2005; Liñán et al. 2008) are ventilated year-round, although the ventilation is more intensive at external temperatures below the cave temperature (Faimon, unpublished work). In static/ semi-dynamic caves, such effects are emphasized under the same conditions.

MLRA only sporadically identified the temperature gradient as a significant predictor of cave $\mathrm{CO}_{2}$ levels (only at sites $\mathrm{C} 2-\mathrm{P}$ and $\mathrm{C} 1-\mathrm{S}$ ). This indicates the minor role of cave ventilation. However, this is contradictory to the estimations of the anthropogenic $\mathrm{CO}_{2}$ share of actual $\mathrm{CO}_{2}$ levels at individual cave sites. Therefore, we guess that the ventilation effect is undervalued. This is especially the case at site C3-P, with its extremely low $\mathrm{CO}_{2}$ levels at low variance. Because the site is unique due to its large free water table surface, the possibility of $\mathrm{CO}_{2}$ dissolution was considered. Based on the analyses of 13 water samples, however, partial pressures of $\mathrm{CO}_{2}$ in the water $\left(\log \mathrm{P}_{\mathrm{CO} 2}=-2.20 \pm 0.26\right)$ exceeded those in the air $\left(\log \mathrm{P}_{\mathrm{CO} 2}=-2.98 \pm 0.35\right)$. Therefore, degassing must be expected instead of dissolution. Based on these facts, the hypothesis about $\mathrm{CO}_{2}$ dissolution was rejected and ventilation remained the sole factor explaining the cave $\mathrm{CO}_{2}$ levels. This is consistent with enhanced temperature variations (Fig. 3). Temperature gradients seem to be an unsuitable proxy for ventilation in case the cave atmosphere is totally exchanged with the external atmosphere, and $\mathrm{CO}_{2}$ levels are nearly constant.

The strong correlation of the $\mathrm{CO}_{2}$ concentrations between different sites (except for site C3-P) indicates the strong mutual dependency of cave sites. The dependence diminishes with site distance.

\section{Spurious relationship problem}

It is well known that statistically related variables (correlated) need not show a causal connection and that the correlation can be the result of a spurious relationship (see, e.g., Ben-Zeev \& Star 2001; Pearl 2009). Therefore, we considered the possibility that between cave $\mathrm{CO}_{2}$ concentrations and other tested variables there is no causal interrelation and that all correlations are the result of external temperature as a confounding factor. A set of linear models was derived, in which external temperature is a unique cave $\mathrm{CO}_{2}$ level predictor. All the models are significant at $\alpha=0.05$ and valid for all the cave sites except for C3-P. These models explain cave $\mathrm{CO}_{2}$ levels by 68 to $77 \%$. We believe that further studying of more sophisticated data (equidistant data with a short distance in the range of hours or minutes) could contribute to a better understanding of the problem.

\section{CONCLUSIONS}

Spatial and temporal variations of carbon dioxide were studied in two sites of the Moravian Karst: (1) soils in the Macocha Plateau with the adjacent Punkevní Caves, and (2) soils in the Sloup-Šošůvka field with the adjacent Sloup-Šošůvka Caves. The soil air $\mathrm{CO}_{2}$ levels, cave air $\mathrm{CO}_{2}$ levels, cave attendance, and external temperatures showed similar seasonality. It was confirmed that soil $\mathrm{CO}_{2}$ production is controlled by temperature/humidity.
Both effects are indistinguishable because of multicollinearity. The impact of vegetation was not proven. Based on multiple linear regression analyses, cave attendance seems to be the most significant variable controlling cave $\mathrm{CO}_{2}$ levels and, subsequently, calcite deposition in the given sites. Temperature gradients and soil $\mathrm{CO}_{2}$ levels were identified as further controlling variables. Because statistical analysis is not able to reveal a causal relation- 
ship, a spurious relationship was considered with external temperature as a lurking variable. To demonstrate such possibility, alternative linear models were derived in which external temperature operates as unique universal predictor of cave $\mathrm{CO}_{2}$ levels.

Two general conclusions may be derived from the study: (1) soils need not necessarily control cave $\mathrm{CO}_{2}$ levels, and (2) the anthropogenic impact may easily superimpose upon natural processes in caves. From the former conclusion, it follows that the speleothem growth rate does not need to be directly related to soil/surface conditions. This is important for palaeoenvironmental reconstructions based on the study of terrestrial speleothems. The latter conclusion is important for karst/cave environment conservation and protection: it shows that the anthropogenic impact in caves is not negligible even if its consequences are not evident or destructive.

\section{ACKNOWLEDGEMENTS}

We would like to thank Dr. Petr Štěpánek from the Czech Hydrometeorological Institute, Regional Office Brno, and Jiří Hebelka, director of the Administration of the Moravian Karst Caves, Blansko, for providing the data on regional temperatures and attendance of open caves, respectively. In addition, we would like to thank two anonymous reviewers for their valuable comments. The work was supported by the MSM0021622412 grant from the Ministry of Education, Youth and Sports of the Czech Republic and by the IGS 2101/541 grant from the VŠB - Technical University of Ostrava, Faculty of Mining and Geology."

\section{REFERENCES}

Atkinson, T.C., 1977: Carbon dioxide in the atmosphere of the unsaturated zone: an important control of groundwater hardness in limestones.- Journal of Hydrology, 35, 111-123.

Balák, I., Jančo, J., Štefka, L. \& P. Bosák, 1999: Agriculture and nature conservation in the Moravian Karst (Czech Republic).- International Journal of Speleology, 28B, 71-88.

Baldini, J.U.L., McDermott, F., Baker, A., Railsback, L.B., Baldini, L.M. \& D.P. Mattey, 2005: Vegetation effects on stalagmite growth rate and isotopic content.- Earth and Planetary Science Letters, 240, 2, 486-494.

Baldini, J.U.L., Baldini, L.M., McDermott, F. \& N. Clipson, 2006: Carbon dioxide sources, sinks, and spatial variability in shallow temperate zone caves: Evidence from Ballynamintra Cave, Ireland.- Journal of Cave and Karst Studies, 68, 4-11.

Baldini, J.U.L., McDermott, F., Hoffmann, D.L., Richards, D.A. \& N. Clipson, 2008: Very high-frequency and seasonal cave atmosphere $\mathrm{PCO}_{2}$ variability: Implications for stalagmite growth and oxygen isotopebased paleoclimate records.- Earth and Planetary Science Letters, 272, 118-129.
Bárány-Kevei, I., 1999: Impact of agriculture land use on some Hungarian karst regions.- International Journal of Speleology, 28B, 89-98.

Ben-Zeev T. \& J.R. Star, 2001: Spurious Correlations in Mathematical Thinking.- Cognition and Instruction, 19, 3, 253-275

Bourges, F., Mangin, A. \& D. d'Hulst, 2001: Le gaz carbonique dans la dynamique de l'atmosphère des cavités karstiques: l'exemple de l'Aven d'Orgnac (Ardèche).Earth and Planetary Sciences, 333, 685-692.

Brovkin, V., Cherkinsky, A. \& S. Goryachkin, 2008: Estimating soil carbon turnover using radiocarbon data: A case-study for European Russia.- Ecological modelling, 216, 178-187.

de Freitas, C.R., Littlejohn R.N., Clarkson T.S. \& I.S. Kristament, 1982: Cave climate: Assessment of airflow and ventilation.- Journal of Climatology, 2, 383-397.

Dreybrodt, W., 1999: Chemical kinetics, speleothem growth and climate.- Boreas, 28, 347-356.

Ek C. \& M. Gewelt, 1985: Carbon dioxide in cave atmospheres. New results in Belgium and comparison with some other countries. Earth Surface Processes \& Landforms, 10, 2, 173-187. 
Faimon, J., Štelcl, J. \& D. Sas, 2006: Anthropogenic $\mathrm{CO}_{2}^{-}$ flux into cave atmosphere and its environmental impact: A case study in the Císařská Cave (Moravian Karst, Czech Republic).- Science of the Total Environment, 369, 231-245.

Fairchild, I.J., Smith, C.L., Baker, A., Fuller, L, Spötl, C., Mattey, D., McDermott, F. \& EIMF, 2006: Modification and preservation of environmental signals in speleothems.- Earth-Science Reviews, 75, 105-153.

Geiger, R., Aron, R. H. \& P. Totdhunter, 2003: The Climate Near the Ground.- Sixth edition,

Rowman \& Littlefield Publishers, Inc., pp. 600, Lanham.

Holland, H.D., Kirsipu, T.V., Huebner, J.S. \& U.M. Oxburgh, 1964: On some aspects of the chemical evolution of cave water.- Journal of Geology, 72, 36-67.

Iqbal, J., Ronggui, H., Lijun, D., Lan, L., Shan, L., Tao, C. \& R. Leilei, 2008: Differences in soil $\mathrm{CO}_{2}$ flux between different land use types in mid-subtropical China.- Soil Biology \& Biochemistry, 40, 23242333.

Jassal, R.S., Black, T.A., Drewitt, G.B., Novak, M.D., Gaumont-Guay, D. \& Z. Nesic, 2004: A model of the production and transport of $\mathrm{CO}_{2}$ in soil: predictiong soil $\mathrm{CO}_{2}$ concentrations and $\mathrm{CO}_{2}$ efflux from forest floor.- Agricultural and Forest Meteorology, 124, 219-236.

Kaufmann, G. \& W. Dreybrodt, 2007: Calcite dissolution kinetics in the system $\mathrm{CaCO}_{3}-\mathrm{H}_{2} \mathrm{O}-\mathrm{CO}_{2}$ at high undersaturation.- Geochimica et Cosmochimica Acta, 71, 1398-1410.

Kuzyakov, Y., 2006: Sources of $\mathrm{CO}_{2}$ efflux from soil and review of partitioning methods.- Soil Biology \& Biochemistry, 38, 425-448.

Li, H.J., Yan, J.X., Yue, X.F. \& M.B. Wang, 2008: Significance of soil temperature and moisture for soil respiration in a Chinese mountain area.- Agricultural and Forest Meteorology, 148, 490-503.

Liñán, C., Vadillo, I. \& F. Carrasco, 2008: Carbon dioxide concentration in air within the Nerja Cave (Malaga, Andalusia, Spain).- International Journal of Speleology, 37, 99-106.

Longdoz, B., Yernaux, M. \& M. Aubinet, 2008: Soil $\mathrm{CO}_{2}$ efflux measurements in a mixed forest: impact of chamber disturbances, spatial variability and seasonal evolution.- Global Change Biology, 6, $907-917$.
Mayers, R.H., 1990: Classical and Modern regression with applications.- Second edition, PWS and Kent Publishing, pp. 488, Boston.

Miotke, F-D., 1974: Carbon dioxide and the soil atmosphere.- Abhandlungen zur Karst-Und Höhlenkunde, Reihe A, Speläologie, 9, 1-49.

Neter, J., Wasserman, W. \& M.H. Kutner, 1989: Applied linear regression models.- Second edition, Richard D. Irwin, pp. 688, Homewood, IL.

Pearl, J., 2009: Causal inference in statistics: An overview.- Statistics Surveys, 3, 96-146.

Rozeboom, W.W., 1979: Ridge regression: Bonanza or beguilement?- Psychological Bulletin, 86, 242-249.

Russell, M.J. \& V. MacLean, 2008: Management issues in a Tasmanian tourist cave: Potential microclimatic impacts of cave modifications.- Journal of Environmental Management, 87, 474-483.

Schmidt, P. \& E.N. Muller, 1978: The problem of multicollinearity in a multistage causal alienation model: A comparison of ordinary least squares, maximumlikelihood and ridge estimators.- Quality and Quantity, 12, 267-297.

Spötl, C., Fairchild, I.J. \& A.F. Tooth, 2005: Cave air control on dripwater geochemistry, Obir Caves (Austria): Implications for speleothem deposition in dynamically ventilated caves.- Geochimica et Cosmochimica Acta, 69, 10, 2451-2468.

Statistica, 2010: StatSoft.- [Online] Available from: http:// www.statsoft.com/ [Accessed 19th October 2010].

Tatár, E., Mihucz, V.G., Tompa, K., Pöppl, L., Záray, G. \& L. Zambó, 2004: Study of soil leachates in doline above the Béke Cave, Hungary.- Geoderma, 120, 155-164.

Troester, J.W. \& W.B. White, 1984: Seasonal fluctuations in the carbon dioxide partial pressure in a cave atmosphere.- Water Resources Research, 20, 153156.

IUSS Working Group WRB, 2006: World reference base for soil resources 2006.- Second edition, World Soil Resources Report number: 103.

Zhang, C., Yuan, D. \& J. Cao, 2005: Analysis of the environmental sensitivities of a typical dynamic epikarst system at the Nongla monitoring site, Guangxi, China.- Environmental Geology, 47, 615-619. 